DARIUSZ MAGIER

ORCID 0000-0001-9367-7448

dmagier@archiwozofia.com

(Uniwersytet Przyrodniczo-Humanistyczny w Siedlcach, Archiwum Państwowe w Siedlcach)

\title{
KLĄTWA BOGDANA KROLLA. PRACOWNICY NAUKOWI I DZIALALNOŚĆ NAUKOWA W POLSKICH ARCHIWACH PAŃSTWOWYCH W ŚWIETLE LITERATURY ARCHIWALNEJ Z XX I XXI W.
}

\begin{abstract}
Słowa kluczowe: archiwa państwowe, archiwiści, badania, Bogdan Kroll, klątwa, nauka, urząd

\section{Streszczenie}

Instytucje archiwalne w Polsce od początku postrzegane były jako placówki naukowe, archiwiści zaś jako pracownicy nauki, którzy z konieczności wykonują również funkcje urzędowe. Do naukowych zadań archiwisty należało porządkowanie akt, sporządzanie inwentarzy, repertoriów, indeksów, udostępnianie akt, przygotowywanie materiałów archiwalnych do druku. Powstałe w latach 50. XX w. określenie archiwalny pracownik działalności podstawowej oznaczało naukowego pracownika archiwalnego. Artykuł, na podstawie literatury archiwalnej, opisuje proces odchodzenia od działalności naukowej w archiwach państwowych w Polsce w II połowie XX i na początku XXI w. oraz towarzyszące temu zjawisko zmniejszania się liczby pracowników naukowych i zastępowania ich personelem, o który z zupełnie innych powodów w końcu lat 50. XX w. upominał się ówczesny pracownik Archiwum Akt Nowych w Warszawie, a późniejszy jego dyrektor, Bogdan Kroll, czyli „,pomocniczymi pracownikami archiwalnymi”. Fakt ten, prowokacyjnie określony klątwą realizującą się obecnie, staje się pretekstem do prześledzenia transmutacji archiwistów archiwów państwowych z pracowników naukowych w urzędników.
\end{abstract}


DARIUSZ MAGIER

ORCID 0000-0001-9367-7448

dmagier@archiwozofia.com

(University of Natural Sciences and Humanities in Siedlce, State Archive in Siedlce)

\title{
THE CURSE OF BOGDAN KROLL. RESEARCHERS AND SCIENTIFIC ACTIVITIES IN POLISH STATE ARCHIVES IN THE LIGHT OF ARCHIVAL LITERATURE FROM THE $20^{\mathrm{TH}}$ AND $21^{\mathrm{ST}}$ CENTURY
}

Keywords: state archives in Poland, archivists, research, Bogdan Kroll, curse, science, office

\begin{abstract}
From the very beginning, archival institutions in Poland were perceived as scientific institutions, while archivists were considered researchers, who by necessity also performed official functions. The archivist's scholarly tasks included organizing files, preparing inventories, repertories, indexes, making files available and preparing archival materials for printing. The old term 'core activity archive worker' meant an archival researcher. Based on archival literature, the article describes the process of departing from scientific activity in the state archives in Poland in the late $20^{\text {th }}$ and early $21^{\text {st }}$ centuries, and the accompanying phenomenon of a decrease in the number of researchers and their replacement by personnel, which for completely different reasons was requested at the end of the $1950^{\text {s }}$ by the then employee and subsequent director of the Archive of New Records in Warsaw, Bogdan Kroll, namely auxiliary archival staff. This fact, provocatively described by the author as a curse that is now being realised, becomes for him an opportunity to trace the transmutation of the archivists of the Polish state archives from researchers to officials.
\end{abstract}




\section{Wprowadzenie}

W pewnym momencie dziejów archiwów państwowych w Polsce archiwistów przestano określać mianem pracowników naukowych. Kiedy się to stało? Bo chyba nie w 1985 r., gdy instytucje naukowe prawnie ograniczono ściśle do jednostek badawczo-rozwojowych, jakimi archiwa państwowe stricte nigdy przecież nie były? Już w latach 50 . XX w. pojawiło się niezgrabne określenie „pracownik działalności podstawowej”, które oznaczało jednak (i tak je wówczas powszechnie rozumiano) naukowego pracownika archiwalnego. Wydawało się, że ustawowe usankcjonowanie pracowników naukowo-badawczych w archiwach w latach 60. utrwali takie postrzeganie archiwistów. Tak się nie stało, włączenie zaś ich do korpusu służby cywilnej w latach 90 . XX w. ${ }^{1}$ zakończyło proces odpływu pracowników naukowych z państwowej służby archiwalnej i zastępowania ich personelem, o który z zupełnie innych powodów w końcu lat 50. upominał się ówczesny pracownik Archiwum Akt Nowych w Warszawie, a późniejszy jego dyrektor, Bogdan Kroll, czyli pomocniczymi pracownikami archiwalnymi. Ten właśnie epizod posłużył w tym artykule jako pretekst do określenia jego postulatu mianem klątwy (Hadrian Ciechanowski opisał jej symptomy na szczeblu centralnym nader szczegółowo), która realizuje się od przełomu XX i XXI w. Wydawało się, że może przemiany w łonie humanistyki, tzw. zwrot postmodernistyczny, pozwolą archiwiście wyzwolić się spod dyktatu polityki historycznej państwa w kierunku swobodnej działalności na rzecz jednostek i zbiorowości lokalnych, a tym samym na powrót zająć się w szerszym zakresie działalnością naukową w sensie archiwistycznym ${ }^{3}$. Okazało się jednak, że technicyzacja życia jeszcze bardziej wtłoczyła go w procedury machi-

${ }^{1}$ Ustawa z dnia 5 lipca 1996 r. o służbie cywilnej (Dz.U. 1996, nr 89, poz. 402). Archiwiści zatrudnieni w archiwach państwowych znaleźli się w korpusie służby cywilnej w grupie pracowników zatrudnionych na stanowiskach urzędniczych w ,urzędach wojewódzkich oraz innych urzędach stanowiących aparat pomocniczy terenowych organów administracji rządowej podległych ministrom lub centralnym organom administracji rządowej”, https://dsc.kprm.gov.pl/korpus-sluzby-cywilnej [dostęp: 03.12.2019].

${ }^{2}$ H. Ciechanowski, Działalność naukowa archiwów państwowych w koncepcjach Naczelnych Dyrektorów Archiwów Państwowych w XXI wieku (Artykut dyskusyjny), „Archeion” 2018, t. 119, s. 317-329.

${ }^{3}$ Byłaby to owa „długa droga od archiwów stanowiących narzędzie władzy, od instytucji, które były aparatem represji i terroru, od pracowni stanowiących azyl naukowych poszukiwań, zarezerwowany tylko dla grup uprzywilejowanych, do miejsc spotkań ludzi, do instytucji kulturotwórczych, których oferta naukowa i popularno-naukowa jest godna uwagi i wpływa na postawy jednostek i zbiorowości”, J. Chojecka, M. Jabłońska, Przestrzenie w archiwach. Archiwa w przestrzeni. Rzecz o obecności archiwów państwowych w świecie i społeczeństwie (referat na XX Powszechny Zjazd Historyków Polskich. Lublin, 18 września 2019 r.), s. 22, https:// xxpzhp.umcs.lublin.pl//Referaty/J.\%20Chojecka\%20M.Jablonska\%20Przestrzenie $\% 20 \mathrm{w} \% 20$ archiwach.\%20Archiwa $\% 20 \mathrm{w} \% 20$ przestrzeni $\% 20$ (NDAP) $\% 20-\% 205 \% 20 I X \% 202019$.pdf [dostęp: 04.10.2019]. 
ny biurowo-urzędniczej dehumanizującej jego pracę ${ }^{4}$, polityka historyczna zaś państwa pozostała, a jeśli nawet zachwieje się w swej tradycyjnej postaci, to za progiem już czeka sterowana odgórnie polityka afirmatywna wobec określonych ideologii, społeczności, środowisk, mniejszości itp. Nihil novi sub sole.

Celem artykułu jest prześledzenie na podstawie literatury archiwalnej dziejów działalności naukowej w archiwach państwowych w Polsce po II wojnie światowej i transmutacji ich kadry „podstawowej” z pracowników naukowych w urzędników. Analiza zmian zachodzących w zawodzie archiwisty pokaże również kierunek rozwoju archiwów i być może pozwoli lepiej zrozumieć zmiany zachodzące w polskim uniwersum archiwalnym.

\section{Archiwa jako placówki naukowe}

Archiwa towarzyszą cywilizacji ludzkiej od tysięcy lat, ale z nauką związały się dopiero na przełomie XVIII i XIX w., gdy po pojawieniu się archiwów $\mathrm{w}$ znaczeniu instytucjonalnym weszły $\mathrm{w}$ orbitę zainteresowania historyków i szybko stały się fundamentem nauki historycznej. Przeobraziło to je ze składów dokumentacji zlikwidowanych instytucji w placówki związane z historiografią ${ }^{5}$ i zapoczątkowało zupełnie nową dla nich i archiwistów epokę - epokę archiwów jako placówek naukowych ${ }^{6}$.

Podobny proces, choć z pewnym opóźnieniem, przebiegał na ziemiach polskich. Archiwa, które powstały w Galicji w II połowie XIX w., czyli Archiwum Krajowe Aktów Grodzkich i Ziemskich we Lwowie oraz Archiwum Krajowe Aktów Grodzkich i Ziemskich w Krakowie, to już sensu stricto archiwa historyczne, a na ich czele stanęli profesorowie Uniwersytetu Jagiellońskiego ${ }^{7}$. Takie są również korzenie archiwów państwowych Niepodległej. Dekret o organizacji archiwów państwowych i opiece nad archiwaliami z 7 lutego 1919 r., choć bardzo ogólnie, ale jednak wyraźnie sygnalizował (art. 2, 4, 5, 11) współdziałanie w działaniach naukowych (,,udostępnianie materiałów archiwalnych drogą publikacji”), co stanowiło podstawę do ,podjęcia prac naukowych, badawczych

${ }^{4}$ W. Chorążyczewski, P. Gut, Historia $\mathrm{w}$ archiwach i archiwa $\mathrm{w}$ historii. Udział archiwów państwowych w rozwoju historiografii polskiej (referat na XX Powszechny Zjazd Historyków Polskich. Lublin, 18 września 2019 r.), s. 1, https://xxpzhp.umcs.lublin.pl//Referaty/W.\%20 Chor\%C4\%85\%C5\%BCyczewski,\%20P.\%20Gut,\%20Historia\%20w\%20archiwach\%20i\%20archiwa $\% 20$ w $\% 20$ historii $\% 20-\% 20$ referat $\% 20$ na $\% 20$ Zjazd $\% 20$ (NDAP) $\% 20-\% 202 \% 20 I X \% 202019$.pdf [dostęp: 04.10.2019]. Na temat wpływu maszyn na pracę archiwisty, zob.: D. Magier, Archiwiści i maszyny, „Archiwa - Kancelarie - Zbiory” 2018, nr 9(11), s. 31-48.

5 W. Chorążyczewski, P. Gut, op.cit., s. 1-3.

${ }^{6}$ M. Łodyński, Archiwiści i bibliotekarze, „Przegląd Biblioteczny” 1937, z. 4, s. 279.

7 S. Ciara, Archiwa a uniwersytety w Krakowie i Lwowie w latach 1877/78-1918, Warszawa 2002, s. 88. 
i edytorskich"». Krystalizowało się przekonanie, że naukowe przejawy funkcjonowania archiwów to clou ich zadań, do których należy: porządkowanie akt, sporządzanie inwentarzy, repertoriów, indeksów, udostępnianie akt badaczom, przygotowywanie materiałów archiwalnych do druku' . To te prace archiwalne staną się podstawą do powstania etosu zawodu archiwisty ${ }^{10} \mathrm{i}$ otaczającej go zewnętrznej aury pociągającej tajemniczości. Założenie przyjęte na progu niepodległości mówiło, że archiwa wymagają personelu posiadającego specjalistyczne wyszkolenie i fachowe przygotowanie naukowe ${ }^{11}$. Jego efektem było powstanie czasopisma „Archeion” oraz ukształtowanie się sytuacji, w której 60 proc. personelu archiwów państwowych (1939 r.) stanowili pracownicy naukowi ${ }^{12}$, wielu zaś dawnych pracowników archiwów znanych jest dziś przede wszystkim jako badacze $^{13}$.

Po II wojnie światowej kierunek rozwoju administracji archiwalnej w stronę działalności naukowej został nie tylko zachowany, czego symbolem było ponowne postawienie Witolda Suchodolskiego na czele reaktywowanego Wydziału Archiwów Państwowych, ale i coraz bardziej wzmacniany przez komunistycznych archiwistów, z Rafałem Gerberem na czele ${ }^{14}$. Efektem tych działań były rozstrzygnięcia Dekretu o archiwach państwowych z 29 marca 1951 r. Wśród podstawowych zadań wymieniono w nim prace naukowo-badawcze i wydawnicze w zakresie archiwistyki i źródeł archiwalnych (art. 4) ${ }^{15}$. Potwierdzał to tymczasowy statut Naczelnej Dyrekcji Archiwów Państwowych wprowadzony zarządzeniem prezesa rady ministrów 31 maja 1951 r., który przewidywał „prowadzenie prac naukowo-badawczych oraz planowanie, kierowanie i nadzorowanie prac naukowo-badawczych archiwów w zakresie archiwistyki i archiwoznawstwa"16.

Ogólny trend został wyrażony również w strukturze Naczelnej Dyrekcji Archiwów Państwowych, gdzie pojawił się Dział Naukowo-Wydawniczy, przy naczelnym dyrektorze zaś reaktywowano Radę Archiwalną, w skład której powo-

${ }^{8}$ Dekret o organizacji archiwów państwowych i opiece nad archiwaliami (Dz.U. 1919, nr 14, poz. 182); zob.: P. Bańkowski, Działalność naukowa i wydawnicza państwowej stużby archiwalnej w Polsce Ludowej, „Archeion” 1964, t. 41, s. 159-160.

${ }^{9}$ M. Motas, O przepisach archiwalnych w Polsce międzywojennej (1918-1939), „Archeion” 1969 , t. 48 , s. $122-123$.

${ }^{10}$ W. Chorążyczewski, P. Gut, op.cit., s. 16.

${ }^{11}$ W. Suchodolski, Potrzeby archiwów państwowych w świetle wniosków zgłoszonych na Wroclawskiej Konferencji Archiwistów, „Archeion” 1948, t. 18, s. 53.

12 A. Tomczak, Rzut oka na dzieje archiwów polskich i na ich aktualne zadania, „Archeion” 1966, t. 43 , s. 279 .

${ }_{13}^{13}$ W. Chorążyczewski, P. Gut, op.cit., s. 3.

${ }^{14}$ P. Bańkowski, Działalność naukowa i wydawnicza..., s. 161.

${ }^{15}$ Dekret z dnia 29 marca 1951 r. o archiwach państwowych (Dz.U. 1951, nr 19, poz. 149).

16 Zarządzenie nr 88 Prezesa Rady Ministrów z dnia 31 maja 1951 r. w sprawie tymczasowego statutu Naczelnej Dyrekcji Archiwów Państwowych (Monitor Polski 1951, nr 55, poz. 722). Zob.: P. Bańkowski, Działalność naukowa i wydawnicza..., s. 161. 
łano przedstawicieli Polskiej Akademii Nauk, uniwersytetów i innych ośrodków naukowych ${ }^{17}$. W tej sytuacji kwestią technicznej korekty było przekazanie archiwów państwowych już w 1958 r. w gestię Ministerstwa Szkolnictwa Wyższego (po okresie podporządkowania Ministerstwu Oświaty w latach 1945-1951, bezpośrednio prezesowi rady ministrów w latach 1951-1956 i Ministerstwu Kultury i Sztuki w latach 1956-1958) ${ }^{18}$.

Zrodzoną wówczas myśl o nadanie archiwom rangi placówek w pełni naukowych podjął nie tylko naczelny dyrektor Gerber, walczący o - jak sam stwierdził - „wykształcenie nowego - naukowego - typu pracownika archiwalnego i przekształcenie archiwów w »prawdziwe instytucje naukowo-badawcze«"19, ale również ogół środowiska archiwalnego reprezentowany w tym czasie m.in. przez Sekcję Archiwalną Związku Zawodowego Pracowników Kultury i Sztuki, którego Zarząd Główny wszczął w tej kwestii działania ${ }^{20}$. Ich efektem była uchwała Rady Ministrów z 27 kwietnia 1962 r., która przyznawała Naczelnej Dyrekcji Archiwów Państwowych i podległym jej archiwom prawa do zatrudniania samodzielnych pracowników nauki, naukowo-badawczych i pomocniczych pracowników naukowo-badawczych oraz przyznanie im przywilejów przysługujących pracownikom naukowym w instytutach naukowych ${ }^{21}$. Rozstrzygnięcia tej uchwały oparte były na Rozporządzeniu Rady Ministrów z 13 września 1961 r., zmienionym 1 lutego 1966 r. i funkcjonującym aż do 31 grudnia 1985 r. $^{22}$

Nie oznaczało to jeszcze przekształcenia archiwów w instytuty naukowe, dawało jednak możliwość posiadania pracowników naukowych sensu stricto. Pro-

${ }^{17}$ P. Bańkowski, Działalność naukowa i wydawnicza..., s. 165.

18 J. Tandecki, Archiwa w Polsce w latach 1944-1989. Zarys dziejów, Torun 2017, s. 26-64.

19 R. Gerber, Cele i zadania stużby archiwalnej w Polsce, „Archeion” 1951, t. 19-20, s. 14; zob. również: P. Bańkowski, Działalność naukowa i wydawnicza..., s. 162.

${ }^{20}$ Zob. np. wystąpienie Ireny Radtke na zebraniu 10 grudnia 1961 r., A. Ptaśnikowa, Zebranie Sekcji Archiwalnej przy Zarządzie Gtównym Zwiazku Zawodowego Pracowników Kultury i Sztuki, „Archeion” 1962, t. 37, s. 291-292; Z. Boda-Krężel, M. Cygański, I. Radtke, Życie naukowe w archiwach $w$ świetle ankiety przeprowadzonej w latach 1962-1963, „Archeion” 1967, t. 47, s. 52. W nurcie zbliżania charakteru pracy archiwistów do nauki historycznej można umieścić również ingerencję władz administracji archiwalnej z 1950 r., polegającą na poleceniu wycofania się archiwistów ze Związku Archiwistów i Bibliotekarzy Polskich, a włączaniu się w działalność Polskiego Towarzystwa Historycznego oraz Towarzystwa Miłośników Historii, gdzie również powstała Sekcja Archiwalna, zob.: W. Chorążyczewski, O zbliżeniu bibliotek $i$ archiwów w związku z petnieniem przez nie funkcji naukowej, [w:] Oblicza archiwów $i$ wspótczesne wyzwania archiwistyki, red. P.A. Czyż i D. Magier, Siedlce 2019, s. 27.

${ }^{21}$ Uchwała nr 164/62 Rady Ministrów z dnia 27 kwietnia 1962 r. w sprawie wykazu archiwów państwowych uprawnionych do zatrudniania pracowników naukowych, „Archeion” 1962, t. 38, s. 271-272.

${ }^{22}$ Rozporządzenie Rady Ministrów z dnia 13 września 1961 r. w sprawie warunków i trybu powoływania pracowników naukowych w instytutach naukowo-badawczych (Dz.U. 1961, nr 43, poz. 228); Rozporządzenie Rady Ministrów z 1 dnia lutego 1966 r. w sprawie powoływania pracowników naukowo-badawczych w instytutach naukowo-badawczych (Dz.U. 1966, nr 10, poz. 62); Ustawa z dnia 25 lipca 1985 r. o jednostkach badawczo-rozwojowych (Dz.U. 1985, nr 36, poz. 170). 
cedura ich powoływania sprawiała, że mogli rzeczywiście czuć się stosunkowo suwerennymi w działaniach pracownikami nauki na podobnym, jak w instytutach naukowych, poziomie. Samodzielnego pracownika naukowego w służbie archiwalnej powoływał minister na wniosek kierownika jednostki przedłożony przez naczelnego dyrektora archiwów państwowych, na pomocniczego pracownika naukowo-badawczego zaś - naczelny dyrektor archiwów państwowych na wniosek kierownika jednostki zatrudniającej ${ }^{23}$. Do procesu opiniowania wniosków kandydatów na samodzielnych pracowników nauki i naukowo-badawczych oraz przeprowadzania postępowania kwalifikacyjnego kandydatów na stanowiska pomocniczych pracowników naukowo-badawczych w archiwach państwowych i Naczelnej Dyrekcji Archiwów Państwowych została włączona również Rada Archiwalna ${ }^{24}$. Pojawiły się postulaty środowiskowe, by unormować zatrudnienie pracowników naukowych i politykę kadrową w tym względzie $\mathrm{w}$ archiwach państwowych ${ }^{25}$.

Na mocy powyższych uchwał i rozporządzeń w latach 1963-1964 zakwalifikowano pierwszych 77 pracowników archiwów państwowych i Naczelnej Dyrekcji Archiwów Państwowych jako pracowników naukowo-badawczych ${ }^{26}$. Na kadrę archiwów państwowych składali się odtąd:

1. pracownicy działalności podstawowej, w tym:

- samodzielni pracownicy nauki,

- pomocniczy pracownicy naukowo-badawczy,

- pozostali;

2. pracownicy pracowni specjalistycznych;

3. pracownicy administracji;

4. pracownicy obsługi ${ }^{27}$.

Obowiązki pracowników naukowo-badawczych zatrudnionych w państwowej służbie archiwalnej zostały określone następująco: „a) zabezpieczanie, gromadzenie, rejestracja, porządkowanie, udostępnianie materiałów archiwalnych, nadzór nad narastającym zasobem archiwalnym, b) prowadzenie prac naukowo-badawczych"28. Zważywszy, że działania te stanowią teoretycznie do dziś klasyczny wachlarz obowiązków każdego archiwisty, ówczesne rozumowanie oparte na przekonaniu, że pracownik naukowy jest „pracownikiem działalności

${ }_{23}$ Zarządzenie nr 15/62 Ministra Szkolnictwa Wyższego z dnia 21 maja 1962 r. w sprawie zatrudnienia pracowników naukowych w archiwach państwowych, „Archeion” 1962, t. 38, s. 273.

${ }^{24}$ Uchwała Rady Archiwalnej z dnia 12 czerwca 1962 r., ibidem, s. 273-274. Procedura powoływania pracowników naukowych w dużym uproszczeniu przypominała dzisiejszą procedurę powoływania dyrektorów i naczelników biur w Instytucie Pamięci Narodowej.

25 W. Chorążyczewski, O zblizeniu bibliotek i archiwów..., s. 30.

26 P. Bańkowski, Działalność naukowa i wydawnicza..., s. 163.

27 J. Kazimierski, Personel archiwów państwowych w latach 1945-1964, „Archeion” 1964, t. 41, s. 37.

28 R.A. [Piotr Bańkowski], Regulamin pracy pracowników naukowo-badawczych zatrudnionych w państwowej stużbie archiwalnej, „Archeion” 1969, t. 51, s. 229. 
podstawowej", wydaje się zrozumiałe. Do czynności określonych stricte jako „prowadzenie prac naukowo-badawczych” zaliczono: przygotowywanie pomocy archiwalnych wyższego rzędu, opracowań z teorii i praktyki archiwalnej oraz wydawnictw ${ }^{29}$, jednakże za szeroko rozumianą działalność naukową uznawano praktycznie do końca XX w. takie działania, jak:

1. Zebrania naukowe $\mathrm{w}$ archiwach, które - obligatoryjnie wprowadzone przez NDAP w 1949 r. - na długie lata stały się głównym jej przejawem. W założeniu miały one: a) ułatwiać pracownikom rozstrzyganie trudności metodycznych w bieżącej pracy; b) zaprawiać młody personel do badań naukowych; c) stanowić rezerwuar artykułów do publikacji archiwalnych $^{30}$.

2. Przygotowanie wstępów do inwentarzy.

3. Inwentaryzacja tematyczna, uważana powszechnie do dzisiaj za jedno z najpoważniejszych przedsięwzięć naukowych archiwistyki polskiej.

4. Współpraca z placówkami naukowymi.

5. Organizacja i udział w konferencjach naukowych.

6. Wydawanie publikacji: czasopism i monografii ${ }^{31}$.

\section{Bogdan Kroll rzuca klątwę}

W atmosferze dążenia do przekształcenia archiwów państwowych w placówki par excellence naukowe, w 1958 r. na łamach czasopisma „Archeion” Bogdan Kroll wyartykułował myśl, której wyrazicielem było zapewne bardzo szerokie grono ówczesnych archiwistów. Konstatował, że konieczność wykonywania prozaicznych prac technicznych, jakich w archiwach jest wiele, odrywa pracowników naukowych archiwów, czyli tzw. pracowników działalności podstawowej, od ich rzeczywistej kluczowej działalności. Rozwiązanie widział zatem w wykształceniu i zatrudnieniu w archiwach nowego typu pracowników - „pracowników archiwalnych ze średnim wykształceniem zawodowym lub ze średnim wykształceniem ogólnokształcącym i [po] poważnym archiwalnym kursie zawodowym”. Dla kadry tej proponował nazwę ,pomocniczy pracownik archiwalny", w odróżnieniu od naukowego pracownika archiwalnego, czyli pracownika działalności podstawowej ${ }^{32}$. Kim byli pracownicy działalności

\footnotetext{
${ }^{29}$ Z. Boda-Krężel, M. Cygański, I. Radtke, op.cit., s. 52.

${ }^{30}$ P. Bańkowski, Działalność naukowo-wydawnicza państwowej służby archiwalnej w Polsce Ludowej, „Archeion” 1955, t. 24, s. 88-89.

${ }^{31}$ Ibidem, s. 89-93.

${ }^{32}$ B. Kroll, W sprawie pomocniczego personelu archiwalnego, „Archeion” 1958, t. 28, s. 11. Notabene zaliczanie pracowników naukowych $\mathrm{w}$ archiwach państwowych do grona pracowników działalności podstawowej mocno niepokoiło Marię Bielińską, gdyż stawiało ich to „w niepokojącej [czyli zbyt dużej - D.M.] odległości od kategorii pracowników nauki, mimo bezspornie naukowego charakteru archiwów", eadem, Stan i zadania archiwów wobec aktualnych potrzeb nauki historycznej, ibidem, 1956, t. 26, s. 16.
} 
podstawowej dla Krolla? - ludźmi z wyższym wykształceniem, przeważnie historycznym, czasem prawniczym, rzadziej ekonomicznym, zazwyczaj uzupełnionym o specjalistyczne wykształcenie archiwistyczne lub praktykę, wykonującymi ,wszystkie prace związane z porządkowaniem i opracowywaniem akt oraz opieką nad narastającym zasobem archiwalnym" "33. Sytuację archiwów bez pracowników pomocniczych porównywał do szpitala, w którym są sami lekarze, bez personelu pielęgniarskiego, zmuszeni - poza wykonywaniem właściwej lekarzom pracy - do takich czynności, jak: mierzenie temperatury, robienie zastrzyków, masaży, opatrunków, podawania lekarstw itp. Dla personelu pomocniczego przewidywał takie zadania, jak: elementy opracowania (prace techniczno-porządkowe przy zespołach o nieskomplikowanej strukturze, sporządzanie części opisu archiwalnego, inwentaryzację jednostek opisanych), ewidencjonowanie nabytków, profilaktyka konserwatorska, wykonywanie prostych kwerend ${ }^{34}$. Był zdania, że rola personelu pomocniczego będzie wzrastać wraz ze wzrostem skuteczności działań nadzoru archiwalnego na przedpolu ${ }^{35}$. Efektem miało być pojawienie się w archiwach państwowych pomocniczego personelu archiwalnego, który ,pozwoli na powstanie w archiwach grupy pracowników naukowych w pełnym i niekwestionowanym znaczeniu tego słowa. Miało to stworzyć sytuację, w której będą oni prowadzić badania archiwalne i historyczne, tworzyć koncepcje metodyczne i konstrukcje archiwalne, a w pewnym sensie także i konstrukcje historyczne, jak np. pisanie wstępów do inwentarzy, będą redagować inwentarze, katalogi, sumariusze, indeksy, opracowywać przewodniki po archiwach i wreszcie zajmować się publikacją źródeł i opracowań archiwalnych. Oceniał, że procentowy stosunek pracowników naukowych $\mathrm{w}$ archiwach do personelu pomocniczego powinien wynosić $40 / 60^{36}$.

Bogdan Kroll częściowo antycypował to, co zdarzyło się w kolejnych dziesięcioleciach w archiwach państwowych, choć niekoniecznie było to zgodne $\mathrm{z}$ jego postulatami. Zalew zasobów materiałami archiwalnymi z,jako tako funkcjonujących" kancelarii rzeczywiście pozwolił na wykonywanie prac archiwalnych przez personel pomocniczy, jednak nie sprawiło to skierowania do zadań merytorycznie bardziej skomplikowanych pracowników naukowych, lecz po prostu zmniejszyło zapotrzebowanie na nich ze strony administracji archiwalnej. Wraz z wygaszaniem działalności naukowej na rzecz urzędowania, personel pomocniczy zdominował archiwa, czego logiczną konsekwencją było to, że nie-

33 B. Kroll, op.cit., s. 11-12.

34 Ibidem, s. 12-13.

35 „Należy przypuszczać, że kiedy ze składnic akt urzędów i instytucji zaczną napływać liczne akta, które nie przechodziły już żadnych kataklizmów, a pochodzą z jako tako funkcjonujących kancelarii, ilość prac wymagających kwalifikacji niższych, niż posiadane przez pracowników działalności podstawowej, będzie wzrastać". Ibidem, s. 13.

36 Ibidem, s. 13-14. 
postrzeżenie ${ }^{37}$ to on przeobraził się w pracowników działalności podstawowej, co wyraziście widać dziś zwłaszcza w ogłoszeniach o naborze na stanowiska archiwistów ${ }^{38}$.

Można zatem stwierdzić, że dążenia środowiska doprowadziły do zmian prawnych, które stworzyły najpierw korzystne warunki do wydzielenia pracowników na etatach naukowych spośród ogółu pracowników, zamienionych z czasem w postulowany przez Krolla personel pomocniczy, a później, przy dekoniunkturze pracy naukowej w archiwach, już bez zmian prawnych spowodowało radykalne zmniejszenie ilości pracowników naukowych aż do ich niemal całkowitego usunięcia z sieci archiwalnej.

\section{Wielki zwrot}

Lata 70., a zwłaszcza 80. XX w. oraz początek XXI w., to czas przekształcania się archiwów w urzędy administracji państwowej i spadek ich aktywności naukowej. Proces ten, któremu towarzyszył wyraźny kryzys opracowania materiałów archiwalnych, odbywał się raczej drogą stosowanych przez administrację archiwalną faktów dokonanych niźli realizacji normatywów prawnych. Ustawa archiwalna z $1983 \mathrm{r} .^{39}$ nie pozostawia przecież wątpliwości co do tego, że działalność naukowa ciągle należy do zakresu działania archiwów państwowych ${ }^{40}$, $\mathrm{w}$ dodatku jest jednym $\mathrm{z}$ podstawowych zadań archiwów, równorzędnym z innymi, choć o charakterze kompetencji pomocniczych, co wynika ze związku z ich zadaniami archiwalnymi. Są jednak prace naukowe strukturalnie wpisane w or-

${ }^{37}$ Ciekawa będzie próba umiejscowienia tego zjawiska w czasie. W 1985 r. pracownicy naukowo-badawczy są w archiwach państwowych jeszcze pracownikami działalności podstawowej. Było ich 100: 5 profesorów, 9 docentów, 64 adiunktów, 17 starszych asystentów i 5 asystentów (B. Woszczyński, Spotkanie profesorów i docentów zatrudnionych w państwowej stużbie archiwalnej, „Archeion” 1987, t. 82, s. 251). W grudniu 1990 r. rozumienie określenia „,pracownik naukowy” jest już właściwie współczesne. W służbie archiwalnej było ich wówczas 67 , odnotowywano przy tym „dużą grupę adiunktów znajdujących się w wieku przedemerytalnym”, co oznaczałoby istnienie „naturalnego" procesu sukcesywnego zmniejszania się liczby pracowników naukowych w archiwach (idem, Spotkanie profesorów i docentów zatrudnionych w państwowej służbie archiwalnej, ibidem, 1994, t. 93, s. 342-343). Proces ten przebiegał bardzo szybko również za sprawą sytuacji ekonomicznej archiwalnych pracowników naukowych, która uruchamiała ich aktywność akademicką (W. Chorążyczewski, P. Gut, op.cit., s. 17), całkowitego zaś niemal oczyszczenia archiwów z etatów naukowych dokonało zaliczenie archiwistów w archiwach państwowych do korpusu służby cywilnej w 1996 r., kiedy to z powodu nieco wyższych pensji w służbie cywilnej, na etaty urzędnicze przeszło gros pracowników naukowych.

${ }^{38}$ Typowe dzisiejsze wymagania zawodowe na stanowisko pracownika działalności podstawowej w archiwum państwowym to: wykształcenie średnie, umiejętność obsługi komputera, znajomość ustawy archiwalnej i podstawowych pojęć archiwalnych.

39 Ustawa z dnia 14 lipca 1983 r. o narodowym zasobie archiwalnym i archiwach (t.j.: Dz.U. 2019, poz. 553).

${ }^{40}$ Ibidem, art. 28, pkt 5. 
ganizację archiwum i mają charakter zinstytucjonalizowany ${ }^{41}$. Tak widzą ich rolę również akademickie środowiska archiwistyczne, które w procesie kształcenia archiwistów nadal kładą duży nacisk na wyposażenie swych absolwentów w kompetencje naukowo-badawcze. Archiwa państwowe, pozostające w równowadze w wypełnianiu swych ustawowych zadań, muszą prowadzić działania naukowe, gdyż są one wpisane w ich ,genotyp”. Pozostaje jedynie wyznaczenie odpowiednich dlań metod pracy, które przyniosą efekty dla pozostałych dziedzin naukowych, zwłaszcza dla historii. „Metody te znajdują ostateczny wyraz w opracowanym naukowo inwentarzu archiwalnym, który, jak wiadomo, jest kluczem do źródła interesującego badacza. Konsekwencje wynikające ze źle opracowanego inwentarza ponosi przede wszystkim sam badacz"42. Istota zawodu archiwisty została ukształtowana w związku z przemianami w nauce historycznej, stąd nieodrodnie związane są z nim takie nauki pomocnicze historii, jak: dyplomatyka, paleografia, a także historia ustroju i prawa ${ }^{43}$. W ostatnich latach zaś ukształtowane już wieloma międzynarodowymi sympozjami dzieje biurokracji ${ }^{44}$.

Prawo archiwalne powierzyło niezmienny od ponad półwiecza zakres archiwalnych prac naukowych nadzorowi naczelnego dyrektora archiwów państwowych $^{45}$. Oznacza to, że głównie od tego organu zależy skala tej działalności, co słusznie zauważył Hadrian Ciechanowski, omawiając zjawisko minimalizowania działalności naukowej od przełomu XX i XXI w. ${ }^{46}$ Główną jego przyczynę widzi z jednej strony $\mathrm{w}$ kryzysie opracowania, $\mathrm{z}$ drugiej $\mathrm{w}$ kryzysie tożsamościowym archiwistów, którego źródłem jest dziś stojąca na rozdrożu i pogrążona w kryzysie działalność archiwalna ${ }^{47}$. Nie dotyczy ona jedynie udostępniania ${ }^{48}$, co znalazło wyraz np. w odgórnym nacisku na przemianowanie pracowni naukowych $\mathrm{w}$ archiwach w czytelnie, z uwagi na cele, do których te pomieszczenia dzisiaj służą, i na charakter współczesnych użytkowników. Niegdyś popularne nazywanie archiwistów „kustoszami akt” było efektem polskiego klasycznego procesu wykształcania się instytucji archiwalnych, uniezależniającego od

${ }^{41}$ A. Klubiński, Prace naukowe jako zobowiazanie archiwów państwowych. Kilka uwag w świetle ustawy o narodowym zasobie archiwalnym i archiwach, „Problemy Archiwistyki” 2009, nr 2(2), s. $12-13$.

42 M. Bielińska, op.cit., s. 4.

43 W. Chorążyczewski, P. Gut., op.cit., s. 13.

44 http://tonik-libra.pl/dzieje-biurokracji/ [dostęp: 21.11.2019].

45 Ustawa z dnia 14 lipca 1983 r. o narodowym zasobie archiwalnym... (art. 21, pkt 1, ust. 5).

${ }^{46}$ H. Ciechanowski, op.cit., s. 317-329.

${ }^{47}$ Zob.: D. Magier, Pracownicy archiwów państwowych w 100-lecie ich istnienia. Próba portretu zbiorowego, „Archiwa - Kancelarie - Zbiory” 2019, nr 10(12), s. 115.

${ }^{4}$ Misja archiwów miała oznaczać ,trwałe zachowanie świadectw przeszłości i zapewnienie do nich powszechnego dostępu w celu wspierania rozwoju państwa i społeczeństwa obywatelskiego", zob.: Strategia archiwów państwowych na lata 2010-2020, Załącznik do Komunikatu nr 1/2010 Naczelnego Dyrektora Archiwów Państwowych z 23 grudnia 2010 r., https:/www.archiwa.gov.pl/images/docs/Strategia archiww pastwowych na lata 2010 2020.pdf [dostęp: 04.10.2019], s. 3. 
„podległości wytwórcom akt”49. Odwrót od nauki, a w konsekwencji coraz powszechniejsze społeczne postrzeganie archiwów jako urzędów, a nie placówek naukowych czy choćby kulturalnych, zaczęło procentować traktowaniem ich również jak typowe instytucje administracji. Już w latach 80 . XX w. zauważano bowiem, tak jak np. Jerzy Pabisz, dyrektor Wojewódzkiego Archiwum Państwowego we Wrocławiu, że „sprowadzanie działalności archiwów do kategorii administracyjnej w pewnym stopniu umniejsza pozycję archiwów i prowadzi do wadliwego przedstawiania właściwej funkcji archiwów. [Nie można zapominać, że] współpraca z przedstawicielami środowisk naukowych pozwoliła pogłębić znaczenie działalności archiwalnej" ${ }^{50}$. Prace naukowe to w archiwum nie niepraktyczna działka, widzimisię pojedynczych pracowników, lecz pożyteczne narzędzie realizacji prac. Dlatego nie można ich oceniać według tych samych kryteriów co działalności placówek naukowych, a raczej w perspektywie funkcjonalności w pracy archiwum. Realizacja zobowiązania archiwum państwowego do prowadzenia badań wymaga spełnienia kryteriów, takich jak: wykorzystanie warsztatu naukowego do opracowania zagadnienia i naukowy charakter wniosków badawczych, instytucjonalny charakter badań i ich związek $\mathrm{z}$ organizacją pracy $\mathrm{w}$ archiwum, ograniczenie tematów do problematyki archiwistycznej lub dziedzin pokrewnych, ograniczenie celowości badań do zakresu zadań realizowanych przez archiwum, ograniczenie przedmiotu badań do zagadnień dotyczących zasobu lub z nim związanych ${ }^{51}$. Oczywistością jest, że bez naukowego opracowania akt, bez naukowego tworzenia pomocy archiwalnych, w tym wyższego rzędu, przygotowania pełnowartościowych pomocy archiwalnych, a zwłaszcza zarzucenie opracowania przewodników po zespołach, nie jest możliwe zadowalające udostępnienie informacji. Technika nie zastąpi pracy naukowej „kustoszów” archiwalnych ${ }^{52}$.

${ }^{49}$ W. Chorążyczewski, P. Gut, op.cit., s. 6.

${ }^{50}$ I. Borowicz, IV Konferencja pracowników naukowo-badawczych archiwów państwowych (omówienie dyskusji), „Archeion” 1982, t. 73, s. 330.

${ }^{51}$ A. Klubiński, op.cit., s. 14-16.

${ }^{52}$ Za swoistą, ale jakże prawdziwą „odę do inwentarza archiwalnego” można uznać następującą opinię Waldemara Chorążyczewskiego i Pawła Guta: „Każdy inwentarz archiwalny, praca wiążąca się z opracowaniem akt zespołu czy zbioru archiwalnego zawsze była i jest nadal obarczona osobowością archiwisty (archiwistów). Jest to autorskie dzieło, choć zawsze obwarowane zasadami archiwistyki, wytycznymi metodycznymi i ograniczeniami systemu informatycznego. Niezależnie od wspomnianych czynników każdy inwentarz książkowy jest różny, posiada swą własną specyfikę, odróżnia się od inwentarzy opracowywanych przez innych archiwistów. Widoczne to jest nie tylko przy pomocach archiwalnych zespołów różnych ustrojowo i kompetencyjnie aktotwórców, ale także przy tożsamych aktotwórcach. W trakcie prac porządkowej nad zespołem, tworząc dla niego inwentarz i wstęp archiwista posługuje się posiadaną wiedzą teoretyczną i umiejętnościami. Jej stan, a także charakter czy osobowość opracowującego dokumenty widoczne są później w zakresie czy jakości fizycznego opracowania akt w magazynie, a także w zakresie jakości, staranności, głębi informacji, itd. opisu archiwalnego zamieszczonego w inwentarzu, w systematyzacji akt, a także we wstępie do inwentarza. Ponadto na inwentarzu książkowym odcisnęła się też praca osoby, która była odpowiedzialna 
Tymczasem to, co zaproponowano archiwom państwowym w końcu XX i pierwszym dwudziestoleciu XXI w., to wyłącznie domena tej dziedziny archiwistyki, którą Włodzimierz Arłamowski za archiwistyką niemiecką nazywał techniką archiwalną, nie będąc przekonany czy w ogóle przynależy ona do nauki $\mathrm{o} \operatorname{archiwach}^{53}$. Nacisk na udostępnianie, przy ograniczaniu roli opracowania (już w założenia godzący w podstawy zawodu archiwisty), przed półwieczem określony zostałby jednoznacznie jako stawianie techniki archiwalnej ponad pracę merytoryczną. Wystarczy powtórzyć choćby zdanie Henryka Altmana, który twierdził, że obsługa użytkowników czy w ogóle udostępnianie, to „czynnik raczej charakteru technicznego. [Zaś] o rzeczywistej roli archiwów [...] stanowi należyta organizacja służby naukowo-informacyjnej w archiwach"54. Jej istotą powinno być „objęcie jednym wspólnym i planowym kierownictwem indywidualnych wysiłków i poczynań określonego grona pracowników naukowych zajmujących się przy użyciu koniecznych środków pracą naukowo-badawczą w określonym zakresie" ${ }^{55}$. Podobne stanowisko można przyjąć w stosunku do współczesnych środków technicznych służących przede wszystkim udostępnianiu, takich jak systemy komputerowe czy sprzęt do digitalizacji, które należy uznać za pomoc techniczną, a nie - jak chcieliby niektórzy - wyznacznik sposobu opracowywania archiwaliów ${ }^{56}$.

Hadrian Ciechanowski jedną z bezpośrednich przyczyn minimalizacji działalności naukowej archiwów widzi w decyzji nr 20 Naczelnego Dyrektora Archiwów Państwowych [Darii Nałęcz] z 10 grudnia 2002 r. w sprawie wprowadzenia wskazówek metodycznych dotyczących uproszczonego opracowania zasobu archiwalnego przechowywanego $\mathrm{w}$ archiwach państwowych, twierdząc, że „wskazówki otworzyły [...] furtkę dla stopniowego odchodzenia od naukowego opracowania zasobu archiwalnego, a więc podstawowej formy działalności naukowej w archiwach, na rzecz masowego uzupełniania baz archiwalnych"s7. W tym sensie akcja retrokonwersyjna narzucona archiwom państwowym w la-

za przygotowanie jego czystopisów, gdyż autor inwentarza, archiwista najczęściej kończył pracę na sporządzeniu pierwopisu, który przejmował pracownik biurowy, aby przepisać go w 3 egzemplarzach na maszynie do pisania. Praca tej osoby miała bardzo istotny wpływ na bezbłędny stan zapisu w inwentarzu opracowanych przez archiwistę opisów jednostek archiwalnych". Eidem, op.cit., s. 8-9.

${ }^{53}$ Miała ona obejmować: „1) zagadnienia związane z budową, urządzeniem i wyposażeniem archiwów, 2) urządzenie pracowni fotograficznych [dziś byłyby to pracownie digitalizacyjne - D.M.] i opracowania metod obróbki dokumentacji mechanicznej oraz 3) zagadnienia konserwacji i restauracji archiwaliów". W. Arłamowski, Postulaty badawcze w zakresie archiwistyki wspótczesnej i organizacja badań, „Archeion” 1962, t. 37, s. 42.

${ }^{54}$ H. Altman, Archiwa w stużbie badań historycznych, ,Archeion” 1960, t. 32, s. 7.

${ }_{55}$ W. Arłamowski, op.cit., s. 44.

${ }^{56}$ W. Chorążyczewski, P. Gut, op.cit., s. 24. Potwierdza to postrzeganie archiwistów, dla których digitalizacja to czynność techniczna, powtarzalna i monotonna, uznawana powszechnie za pozostająca poniżej ich wiedzy i możliwości, zob.: D. Magier, Pracownicy archiwów państwowych ..., s. 116-118.

${ }^{57}$ H. Ciechanowski, op.cit., s. 319. Zob. również: E. Galik, Dokąd zmierzasz archiwistyko? Rozważania na temat kondycji polskich archiwów państwowych $w$ świetle wspótczesnych tendencji 
tach 2018-2019, która zachwiała resztkami złudzeń, że zachowują one równowagę pomiędzy wykonywaniem zadań urzędu i instytucji naukowo-kulturalnej, przypomina (potępione w późniejszym okresie przez środowisko archiwalne) akcje prowadzone $\mathrm{w}$ pierwszej połowie lat 50 . XX w. inwentaryzacji tematycznych (np. materiałów do historii ruchu robotniczego i klasy robotniczej, dziejów wsi i chłopa polskiego, dziejów rewolucji 1905-1907, historii stosunków polsko-sowieckich w latach 1918-1939). Prace te, choć ,ułatwiające badania naukowe pewnej grupie [...], stały się przyczyną opóźnienia szerszego udostępnienia materiałów źródłowych w archiwach dla potrzeb nauki historycznej w ogólności" ${ }^{58}$. Retrokonwersja dodatkowo stała się zwieńczeniem narastającego niezadowolenia i w efekcie frustracji archiwistów zamienionych w ,wypełniaczy" baz danych ${ }^{59}$.

Co ciekawe, działalność naukowa archiwów znajduje przeciwników zarówno wśród zwolenników zamieniania archiwów państwowych w urzędy, jak i tych, którzy oczekują maksymalizacji zadań w zakresie szeroko pojętej popularyzacji. Tłumaczenia oporu archiwistów wobec narzucanych odgórnie zmian w funkcjonowaniu archiwów, odrywających je de facto od korzeni, były i są różnorakie: od zbędności badań naukowych w pracy archiwalnej lub deprecjonowania ich roli jako ,zbędnej (z pragmatycznego punktu widzenia zbyt teoretyzującej) »konarszczyzny «" ne prace archiwalne, to wina pamięci ,utrwalonego w kolejnych pokoleniach "naukowych « archiwistów przekonania, że w obszarze ich zainteresowania pozostaje tzw. praca wewnętrzna archiwów, jako ważniejsza”, i strach, że „pod naporem archiwalnych edukatorów, popularyzatorów, nierzadko sympatyzujących z nieprofesjonalnymi historykami i »pseudonaukowcami«, z archiwów znikną etatowi naukowcy?" ${ }^{11}$ Wyraźny nacisk na udostępnianie i popularyzację pojawił się w II dekadzie XXI w. i urzędowo został wyartykułowany w Strategii archiwów państwowych na lata 2010-202062, która kładła nacisk na działalność edukacyjną przy jednoczesnym pominięciu działalności naukowej, czego trudno nie wiązać z likwidacją Zakładu Naukowego Archiwistyki w NDAP ${ }^{63}$.

Wyznaczający taką politykę próbowali godzić rzeczy nie do pogodzenia, czyli kłaść nacisk na popularyzację i działalność edukacyjną, wygaszając jednocześnie działania naukowe, co w rzeczywistości powodowało wyjaławianie

\footnotetext{
rozwojowych, [w:] Archiwistyka między różnorodnościa a standardyzacją, Toruńskie Konfrontacje Archiwalne, t. 3, red. W. Chorążyczewski, A. Rosa, Toruń 2013, s. 65.

${ }^{58}$ M. Bielińska, op.cit., s. 5.

59 D. Magier, Pracownicy archiwów państwowych..., s. 170-120.

${ }^{60}$ A. Klubiński, op.cit., s. 14-15.

${ }^{61}$ J. Chojecka, M. Jabłońska, op.cit., s. 4.

${ }^{62}$ Strategia archiwów państwowych...

${ }^{63}$ Zob.: H. Ciechanowski, op.cit., s. 322-323.
} 
tych pierwszych i zmuszało do posługiwania się owocami prac naukowych innych podmiotów. Efektem jest coraz częstsze posługiwanie się archiwów państwowych w działaniach edukacyjnych np. wydawnictwami Instytutu Pamięci Narodowej (książki, komiksy, przede wszystkim gry), co może rodzić pytanie, czy efektem takich działań jest rzeczywiście podnoszenie wiedzy o archiwach państwowych i ich zasobie? Czy archiwista oderwany od klasycznej archiwistyki będzie efektywnym pracownikiem archiwum? Trudno przecież zaprzeczyć, że „badania naukowe, kontakty z instytucjami badawczymi poszerzają wiedzę i umiejętności archiwistów, poszerzają ich horyzonty, co na pewno sprzyja tworzeniu doskonalszych pomocy archiwalnych dla opracowywanych zespołów i zbiorów archiwalnych" ${ }^{64}$, a tym samym niebagatelnie wpływa na jakość udostępniania akt we wszystkich jego postaciach i działalność edukacyjno-popularyzatorską.

Przez ostatnie lata ustawowy wymóg prowadzenia działalności naukowej próbowano statystycznie wypełnić indywidualnymi działaniami archiwistów prowadzonymi poza godzinami pracy zawodowej. Gwoli przyzwoitości należy jednak zerwać z tym procederem i rozróżnić działalność naukową archiwów od działalności naukowej archiwistów ${ }^{65}$. Dlatego warto powtórzyć opinię Mariana Friedberga, że „badań z dziedziny archiwistyki nie można traktować zawsze tylko jako prywatnego, dodatkowego wkładu archiwistów do ich pracy zawodowej, ale badania te, stanowiące przecież podstawę naukowego rozwoju naszej nauki, muszą wejść do służbowych obowiązków archiwisty, a więc znaleźć miejsce w planach prac archiwów. Organizować odpowiednio pracę, a więc systematycznie rozdzielać opracowanie zagadnień ważnych, a dotąd należycie nie zbadanych, można przecież tylko w ramach pracy obowiązkowej, a nie prywatnych inicjatyw, zależnych wyłącznie od zainteresowań poszczególnych archiwistów"66. To zaś oznacza konieczność utrzymania stałych związków archiwów z ośrodkami akademickimi ${ }^{67}$.

Próbę zmiany polityki względem działalności naukowej w archiwach podjął naczelny dyrektor archiwów państwowych Władysław Stępniak, którego staraniem uchwalono Ustawę z 20 marca 2015 r. o zmianie ustawy o narodowym zasobie archiwalnym i archiwach ${ }^{68}$. W znowelizowanym art. 40 przewidziano możliwość zatrudniania $\mathrm{w}$ archiwach pracowników naukowych, lecz z powodu braku rozporządzeń wykonawczych pozostaje on do dzisiaj martwy.

\footnotetext{
${ }^{64}$ W. Chorążyczewski, P. Gut, op.cit., s. 24.

${ }^{65}$ Ibidem, s. 15.

${ }_{66}$ M. Friedberg, Najważniejsze zadania badawcze archiwisty, „Archeion” 1962, t. 37, s. 66-67.

${ }^{67}$ Zob.: I. Sułkowska-Kurasiowa, Wyniki narad archiwów państwowych z przedstawicielami nauki w sprawie koordynacji planów naukowych, „Archeion” 1968, t. 48, s. 175-176.

${ }^{68}$ Ustawa z dnia 20 marca 2015 r. o zmianie ustawy o narodowym zasobie archiwalnym i archiwach (Dz.U. 2015, poz. 566).
} 
Wydarzeniem nawiązującym do spotkań środowisk archiwalnych i akademickich z lat 60. i 70. XX w. było zorganizowanie spotkania przedstawicieli NDAP i środowisk akademickich 11 lipca 2018 r., chociaż z uwagi na próbę przesunięcia ciężaru działalności naukowej z archiwów państwowych na środowiska akademickie, jedynie przy wsparciu indywidualnych działań pracowników archiwów, można je określić nawiązaniem à rebours ${ }^{69}$. Tym bardziej że powołana w efekcie spotkania Rada Naukowa ds. Współpracy Naczelnej Dyrekcji Archiwów Państwowych i archiwów państwowych ze środowiskami naukowymi archiwistyki w Polsce ${ }^{70}$ właściwie nie rozpoczęła dotychczas działalności.

\section{Ku nieznanemu. Zakończenie}

Odwrót od działalności naukowej w archiwach państwowych pozbawia archiwistów nie tylko tradycji i atrakcyjnej przynależności do swoistego zakonu funkcjonującego w obrębie dziedzictwa historycznego, ale także stymuluje ich dalszą transmutację, która sprawia, że przestają być kontynuatorami działań zrodzonych w średniowiecznej kaplicy, podejmujących i doskonalących dzieło Natury (a przy tym również siebie samych), a przeobrażają się jedynie w bezwolne elementy bezdusznego biurokratycznego systemu. W urzędników. Tracą na tym w postrzeganiu przez opinię społeczną zarówno oni, jak i cała struktura archiwów państwowych, ale również wymagający merytorycznie użytkownik, którego porozumienie się z archiwistą pozbawionym podstaw naukowych wkrótce może stanąć pod znakiem zapytania ${ }^{71}$. Retorycznym pozostaje pytanie, co zyskuje archiwista, przestając być naukowcem (,,z odpowiednio ukształtowaną wrażliwością historyczną, gdy gromadzi zasób archiwalny, gdy przygotowuje go do udostępnienia i wreszcie, gdy je udostępnia światu naukowemu"), skoro ustawowy walor historyczny jest jedynym uzasadnieniem przechowywania archiwaliów? ${ }^{72}$

${ }^{69}$ Zob. H. Ciechanowski, op.cit., s. 326.

${ }^{70}$ Zarządzenie nr 68 Naczelnego Dyrektora Archiwów Państwowych z dnia 28 września 1918 r. w sprawie powołania Rady Naukowej ds. Współpracy Naczelnej Dyrekcji Archiwów Państwowych i archiwów państwowych ze środowiskami naukowymi archiwistyki w Polsce, https://archiwa.gov.pl/ files/zarz68_2018.pdf [dostęp: 21.11.2019].

71 „Praca naukowa archiwistów jako historyków lub we współpracy z historykami spoza archiwów w zakresie historii, nauk pomocniczych historii, edycji źródeł jest elementem udostępniania dziedzictwa archiwalnego społeczeństwu, ale też samoistnie stanowi też wstęp i pomoc w naukowym opracowaniu zasobu archiwów" - W. Chorążyczewski, P. Gut, op.cit., s. 23.

${ }^{72}$ Ibidem, s. 26. Warto zauważać, że w klasycznej roli widzi siebie nadal znaczna część współczesnych archiwalnych , pracowników działalności podstawowej”. Niemal 34 proc. uważa, że opracowanie stanowi „istotę pracy archiwalnej”, dla 32 proc. zaś opracowanie jest czynnością, którą chcieliby wykonywać najbardziej, zob.: D. Magier, Wyniki ankiety „Opracowanie w archiwach państwowych AD 2018", http://archiwozofia.com/single-post/2019/07/17/Wyniki-ankiety-Opracowanie-w-archiwach-pa\%C5\%84stwowych-AD-2018 [dostęp: 21.11.2019]. 
Kierunek rozwoju archiwów państwowych zapoczątkowany w końcu XX i kontynuowany w XXI w. jest krokiem ku nieznanej dotąd w Polsce formule. Trudno powiedzieć, czy to formuła dobra czy też zła, a proces nieodwracalny? Istotne, że ona już jest, rodzi się na naszych oczach.

\section{Źródła}

Dekret o organizacji archiwów państwowych i opiece nad archiwaliami (Dz.U. 1919, nr 14, poz. 182).

Dekret z dnia 29 marca 1951 r. o archiwach państwowych (Dz.U. 1951, nr 19, poz. 149).

Zarządzenie nr 88 Prezesa Rady Ministrów z dnia 31 maja 1951 r. w sprawie tymczasowego statutu Naczelnej Dyrekcji Archiwów Państwowych (Monitor Polski 1951, nr 55, poz. 722).

Rozporządzenie Rady Ministrów z dnia 13 września 1961 r. w sprawie warunków i trybu powoływania pracowników naukowych w instytutach naukowo-badawczych (Dz.U. 1961, nr 43, poz. 228).

Rozporządzenie Rady Ministrów z dnia 1 lutego 1966 r., w sprawie powoływania pracowników naukowo-badawczych w instytutach naukowo-badawczych (Dz.U. 1966, nr 10, poz. 62).

Strategia archiwów państwowych na lata 2010-2020, Załącznik do Komunikatu nr 1/2010 Naczelnego Dyrektora Archiwów Państwowych z 23 grudnia 2010 r., https://www.archiwa.gov.pl/ images/docs/Strategia_archiww_pastwowych_na_lata_2010 2020.pdf [dostęp: 04.10.2019]

Ustawa z dnia 14 lipca 1983 r. o narodowym zasobie archiwalnym i archiwach (t.j.: Dz.U. 2019, poz. 553).

Ustawa z dnia 25 lipca 1985 r. o jednostkach badawczo-rozwojowych (Dz.U. 1985, nr 36, poz. 170).

Ustawa z dnia dnia 5 lipca 1996 r. o służbie cywilnej (Dz.U. 1996, nr 89, poz. 402).

Ustawa z dnia 20 marca 2015 r. o zmianie ustawy o narodowym zasobie archiwalnym i archiwach (Dz.U. 2015, poz. 566).

\section{Bibliografia}

Altman H., Archiwa w stużbie badań historycznych, „Archeion” 1960, t. 32, s. 3-11.

Arłamowski W., Postulaty badawcze $w$ zakresie archiwistyki współczesnej $i$ organizacja badań, „Archeion” 1962, t. 37, s. 27-47.

Bańkowski P., Działalność naukowo-wydawnicza państwowej stużby archiwalnej w Polsce Ludowej w latach 1944-1954, „Archeion” 1955, t. 24, s. 87-97.

Bańkowski P., Działalność naukowa i wydawnicza państwowej stużby archiwalnej w Polsce Ludowej, „Archeion” 1964, t. 41, s. 159-179.

Bielińska M., Stan i zadania archiwów wobec aktualnych potrzeb nauki historycznej, „Archeion” 1956, t. 26, s. 3-17.

Boda-Krężel Z., Cygański M., Radtke I., Życie naukowe $w$ archiwach $w$ świetle ankiety przeprowadzonej w latach 1962-1963, „Archeion” 1967, t. 47, s. 51-71. 
Borowicz I., IV Konferencja pracowników naukowo-badawczych archiwów państwowych (omówienie dyskusji), „Archeion” 1982, t. 73, s. 325-331.

Chojecka J., Jabłońska M., Przestrzenie w archiwach. Archiwa w przestrzeni. Rzecz o obecności archiwów państwowych w świecie i społeczeństwie (referat na XX Powszechny Zjazd Historyków Polskich. Lublin, 18 września 2019 r.), https://xxpzhp.umcs.lublin.pl//Referaty/J.\%20 Chojecka\%20M.Jablonska\%20Przestrzenie \%20w\%20archiwach.\%20Archiwa\%20w\%20 przestrzeni $\% 20$ (NDAP)\%20-\%205\%20IX\%202019.pdf [dostęp: 04.10.2019].

Chorążyczewski W., O zbliżeniu bibliotek i archiwów w związku z petnieniem przez nie funkcji naukowej, [w:] Oblicza archiwów i wspótczesne wyzwania archiwistyki, red. P.A. Czyż i D. Magier, Siedlce 2019, s. 21-43.

Chorążyczewski W., Gut P., Historia w archiwach i archiwa w historii. Udział archiwów państwowych w rozwoju historiografii polskiej (eferat na XX Powszechny Zjazd Historyków Polskich. Lublin, 18 września 2019 r.), https://xxpzhp.umcs.lublin.pl//Referaty/W.\%20 Chor\%C4\%85\%C5\%BCyczewski,\%20P.\%20Gut,\%20Historia\%20w\%20archiwach\%20 i\%20archiwa $\% 20$ w $\% 20$ historii $\% 20-\% 20$ referat $\% 20$ na $\% 20$ Zjazd $\% 20$ (NDAP) $\% 20-\% 20$ 2\%20IX\%202019.pdf [dostęp: 04.10.2019].

Ciara S., Archiwa a uniwersytety w Krakowie i Lwowie w latach 1877/78-1918, Warszawa 2002.

Ciechanowski H., Działalność naukowa archiwów państwowych w koncepcjach naczelnych dyrektorów archiwów państwowych w XXI w., „Archeion” 2018, t. 119, s. 317-331.

Friedberg M., Najważniejsze zadania badawcze archiwisty, „Archeion” 1962, t. 37, s. 64-69.

Galik E., Dokad zmierzasz archiwistyko? Rozważania na temat kondycji polskich archiwów państwowych w świetle wspótczesnych tendencji rozwojowych, [w:] Archiwistyka między różnorodnościq a standardyzacja, Toruńskie Konfrontacje Archiwalne, t. 3, red. W. Chorążyczewski, A. Rosa, Toruń 2013, s. 55-103.

Kazimierski J., Personel archiwów państwowych w latach 1945-1964, „Archeion” 1964, t. 41, s. 31-39.

Klubiński A., Prace naukowe jako zobowiązanie archiwów państwowych. Kilka uwag w świetle ustawy o narodowym zasobie archiwalnym i archiwach, „Problemy Archiwistyki” 2009, nr 2(2), s. 12-16.

Kroll B., W sprawie pomocniczego personelu archiwalnego, „Archeion” 1958, t. 28, s. 11-21.

Łodyński M., Archiwiści i bibliotekarze, „Przegląd Biblioteczny” 1937, z. 4, s. 270-289.

Magier D., Archiwiści i maszyny, „Archiwa - Kancelarie - Zbiory” 2018, nr 9(11), s. 31-48.

Magier D., Pracownicy archiwów państwowych w 100-lecie ich istnienia. Próba portretu zbiorowego, „Archiwa - Kancelarie - Zbiory” 2019, nr 10(12), s. 111-121.

Magier D., Wyniki ankiety „Opracowanie w archiwach państwowych AD 2018”, http://archiwozofia.com/single-post/2019/07/17/Wyniki-ankiety-Opracowanie-w-archiwach-pa\%C5\%84stwowych-AD-2018 [dostęp: 21.11.2019].

Motas M., O przepisach archiwalnych w Polsce międzywojennej (1918-1939), „Archeion” 1969, t. 48 , s. $111-137$.

Ptaśnikowa A., Zebranie Sekcji Archiwalnej przy Zarządzie Głównym Związu Zawodowego Pracowników Kultury i Sztuki, „Archeion” 1962, t. 37, s. 129-136. 
R.A. [Bańkowski Piotr], Regulamin pracy pracowników naukowo-badawczych zatrudnionych w państwowej stużbie archiwalnej, „Archeion” 1969, t. 51, s. 221-231.

Suchodolski W., Potrzeby archiwów państwowych w świetle wniosków zgłoszonych na Wrocławskiej Konferencji Archiwistów, „Archeion” 1948, t. 18, s. 47-60.

Sułkowska-Kurasiowa I., Wyniki narad archiwów państwowych z przedstawicielami nauki w sprawie koordynacji planów naukowych, „Archeion” 1968, t. 48, s. 174-178.

Tandecki J., Archiwa w Polsce w latach 1944-1989. Zarys dziejów, Torun 2017.

Tomczak A., Rzut oka na dzieje archiwów polskich i na ich aktualne zadania, „Archeion” 1966, t. 43, s. $55-82$.

Woszczyński B., Spotkanie profesorów i docentów zatrudnionych w państwowej stużbie archiwal$n e j$, ,Archeion” 1987, t. 82, s. 250-253.

Woszczyński B., Spotkanie profesorów i docentów zatrudnionych w państwowej stużbie archiwal$n e j$, ,Archeion” 1994, t. 93, s. 341-344.

Zatrudnianie pracowników naukowych w archiwach państwowych, „Archeion” 1962, t. 38, s. $271-274$. 